\title{
Análise morfológica comparativa: a rede das vilas de Itapeva, Apiaí e Itapetininga fundadas no território paulista sob o governo do Morgado de Mateus
}

Dossier REde URbana E DeFiniÇão das FronteIRAs PaUlistaS

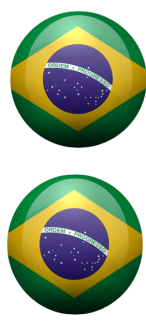

\section{Caio Guedes}

Mestrando em Urbanismo pela Pontifícia Universidade Católica de Campinas. Arquiteto e Urbanista. Sorocaba [SP] Brasil <caio.guedes@hotmail.com.br>.

\section{Ivone Salgado}

Professora Titular da Pontifícia Universidade Católica de Campinas (FAU e POSURB). Arquiteta Urbanista, Doutorado pelo Institut d'Urbanisme de Paris - Université de Paris XII e Pós-doutorado junto ao Istituto Universitario di Architettura di Venezia. Campinas [SP] Brasil <salgadoivone@puc-campinas.edu.br>.

\section{Resumo}

Este trabalho investiga o ideário urbano no processo de elevação de algumas freguesias a vila no período colonial, com estudo de caso de freguesias do termo de Sorocaba elevadas a vila no governo do Morgado de Mateus (1765-1775): Itapeva da Faxina (1769), Itapetininga (1771) e Apiaí (1771). Elas se localizavam na parte meridional da Colônia, numa rota comercial entre Sorocaba e Curitiba. 0 método utilizado compreende análise comparativa entre as formações urbanas quando da fundação das vilas, reconstituindo as práticas e discursos envolvidos nas elevações com os centros históricos atuais, procurando verificar as permanências e rupturas dos modelos formais idealizados de cidade, através de seus espaços construídos. Para isso foram utilizadas documentações do governo paulista do período enquanto fontes primárias, fotografias e softwares para interpretação da cartografia histórica com os recursos de imagem atual de satélite, espacializando as diversas configurações desses centros urbanos, no passado e no presente.

\section{Palavras-chave}

Elevação de vilas. Cidade colonial. Morfologia urbana. Urbanismo.

\section{Comparative morphological analysis: the network of the villages of Itapeva, Apiai and Itapetininga founded in the territory of São Paulo under the government of Morgado de Mateus}

\begin{abstract}
This work investigates the urban ideals in the process of elevation of some freguesias to the village in the colonial age, with the case study of freguesias from the term of Sorocaba, elevated in village at the government of Morgado de Mateus (1765-1775): Itapeva da Faxina (1769), Itapetininga (1771) and Apiai (1771). They were located in the southern part of the Colony, on a commercial route between Sorocaba and Curitiba. The method used includes comparative analysis of urban forms at the foundation of the villages, reconstructing the practices and discourses involved in the elevations with the current historical centers, trying to verify the maintenances and ruptures of the idealized formal models of the city through their built spaces. For this purpose, documents of the São Paulo government of the period were used as primary sources, photographs and software for interpreting historical cartography with the current satellite image resources, spatializing the different configurations of these urban centers, in the past and present.
\end{abstract}

\section{Keywords}

Elevations of villages. Cologne city. Urban morphology. City planning. 


\section{Introdução}

O presente trabalho analisou a morfologia dos núcleos urbanos de Itapeva da Faxina, elevada a vila em 1769 (atual município de Itapeva), Itapetininga e Apiaí, elevadas a vila em 1771, em território do atual estado de São Paulo. Essas três vilas foram desmembradas do termo da Vila de Nossa Senhora da Ponte de Sorocaba (atual município de Sorocaba) ganhando autonomia política e administrativa. Valendo-se da cartografia histórica e documentação primária, propõe-se a interpretação das rupturas e permanências dos aspectos morfológicos relativos ao tecido urbano.

\subsection{O contexto histórico das vilas coloniais no século XVIII}

O século XVIII irrompe o caráter de modernidade nas cidades Europeias. Em Portugal, através da administração de Sebastião José de Carvalho e Melo, o Marquês de Pombal (1750-1777), temos o exemplo da reconstrução da Baixa de Lisboa. A necessidade da rápida reconstrução da cidade, após o terremoto, permitiu a reconfiguração da capital Portuguesa, com uma racionalização do espaço. Esse método racional, proporcionado pela quadrícula ortogonal, foi um modelo adequado aos anseios sociais e administrativos da época. Podemos observar que, ao longo do mesmo século, são vistos exemplos de implantação de vilas na colônia com este mesmo aspecto. A necessidade de rápidas elevações de povoados a vila nas Capitanias do Sul, através da administração do Morgado de Mateus, revela a extensão do pensamento iluminista de Pombal, entre outros aspectos, no que se refere à organização do traçado urbano e da rede urbana.

Uma dinâmica hierárquica de núcleos urbanos, estabelecida como via-de-regra na colônia portuguesa é assunto consagrado por Murillo Marx (1991) e outros autores do século XX1. Compreender a forma como estavam organizados os territórios da Colônia no século XVIII, permite chegar ao entendimento de que em 1750, apresentavam-se "sérios obstáculos a um controle mais efetivo do território" (Derntl, 2010, p.33). Assim, o processo de elevação de um arraial ou povoado às categorias hierarquizadas de capela, freguesia e vila, como esclarece Murillo Marx (1991), demonstra as estratégias urbanizadoras delegadas ao Clero, enquanto instalação de uma rede eclesiástica na colônia portuguesa nas Américas, desde o início da colonização, no século XVI. Sobre isso relata Beatriz Bueno:

A rede eclesiástica precedia a rede civil e, em termos jurídicos, ficava submetida a ela. Através da Igreja, de suas instâncias de base, umbilicalmente ligadas às do próprio Estado, a institucionalização de povoados dispersos dava-se, inicialmente, pela oficialização de sua ermida. A elevação de uma comunidade ao estatuto de capela curada significava a ascensão de uma região inóspita a núcleo reconhecido pela Igreja e também a garantia de visita de um pároco. Tanto o acesso à assistência religiosa como o reconhecimento de fato e de direito perante a Igreja e o Estado motivavam a solicitação junto ao bispado. A subsequente elevação à condição de freguesia garantia o acesso ao batismo, ao casamento, ao amparo dos enfermos, aos sacramentos, aos registros de nascimento, de matrimônio, de óbito, com todas suas implicações jurídicas e sociais. Para além do acesso ao rito litúrgico, a elevação de uma capela a freguesia implicava em usufruto da formalidade civil (Bueno, 2009, p. 252).

A vila, por sua vez, exercia importante função administrativa quando da instalação da Casa de Câmara e Cadeia e do Pelourinho, este símbolo da ordem civil. A vila congregava, muitas vezes, várias outras freguesias em seu termo - delimitação de território sob a jurisdição da Câmara.

Segundo Nestor Goulart Reis (2013), o papel de Estado delegado ao poder eclesiástico, bem como os processos sociais decorridos ao longo dos séculos XVI e XVII, levaram a uma espacialização do que compreendemos aqui como o território das capitanias do Sul. Esta foi criada em 1608, pela divisão do Governo Geral do Brasil e faziam parte dessa divisão, as capitanias do Espírito Santo, São Tomé, Rio de Janeiro, Santo Amaro, São Vicente, e Sant'Ana. Ainda, segundo o mesmo autor, o ciclo da exploração do ouro das Minas Gerais consagrado no século XVIII foi precedido por um ciclo de exploração efetivado na Repartição Sul, que se iniciou com a ocupação dos sertões de São Paulo, no final do século XVI. Podemos encontrar em Reis (2013) que, o primeiro ciclo de exploração,

${ }^{1}$ Entre eles destacamos Nestor Goulart Reis (1968, 2013), Ruy Moreira (2014) e Beatriz P. S. Bueno (2009). 
ocorrido nas capitanias do Sul se deu entre 1593 a 1697 e o segundo nas Minas Gerais, Mato Grosso e Goiás. Para adentrar aos sertões do território, utilizava-se da mão de obra indígena em sua maioria. Conta-nos o autor que a Rede Urbana da repartição Sul era maior do que a rede da repartição Norte, firmando sua importância em um contexto geral, por ter iniciado seus processos de adentramento antes da região Norte (Reis, 2013, p.30).

As vilas aqui estudadas fazem parte do território, das capitanias do Sul. Destacaremos no presente artigo a Vila de Apiaí, que segundo Reis, têm importância no contexto regional desse período séc. XVII - devido a vários afluentes do Rio Apiaí serem auríferos, como o córrego Frias na atual cidade de Apiaí e a própria exploração do Morro do Ouro (Reis, 2013, p.103).

A rede urbana que se instalou nas capitanias do Sul, começava a denunciar em meados do século XVIII, sérios problemas. Uma dificuldade de homogeneização do território se dava pela dispersa rede de vilas, freguesias e povoados, conectados através das lógicas sociais e econômicas e concentrados em sua maioria no litoral, demonstrando ainda, pouco acesso aos Sertões. A fragilidade dos limites era preocupação recorrente para a Coroa. Invasões espanholas eram eminentes. Foram necessárias medidas para resolver as dificuldades, como a cobrança de impostos, recrutamento militar e a administração jurídica.

\section{A ocupação das capitanias Sul e o Caminho do Viamão}

A ocupação das capitanias do Sul permaneceu como território de conflito entre portugueses e espanhóis durante os séculos XVII e XVIII. Em 1680, o Governador do Rio de Janeiro D. Manuel Lobo alcançou a região do Rio da Prata e iniciou a construção de uma fortaleza e uma povoação ao seu redor que se denominaria Colônia do Santíssimo Sacramento, onde hoje se encontra a cidade uruguaia de Colônia. O governador espanhol de Buenos Aires, D. José de Garro, no mesmo ano, ordenou o ataque a Colônia e fez prisioneiro D. Manuel Lobo, que viria a falecer logo em seguida.

Em 1681, foi assinado um tratado em Lisboa que passaria a Colônia para os portugueses, fato consumado somente em 1683. Entre 1704 e 1705, os espanhóis atacaram várias vezes Colônia, arrasando-a e fazendo os portugueses abandonarem o local. Este seria reconstruído, já sob o domínio espanhol. Pelo Tratado de Utrecht, de 1715, Colônia voltava ao domínio português. Entre 1735 e 1737, os espanhóis mantiveram novamente sob cerco os portugueses, sob ordens de D. Miguel de Salcedo. Somente com o Tratado de Paris de 1737 determinou-se um armistício. Neste período, se desenvolveria na região Montevidéu e seria fundada a cidade de Rio Grande. 0 Tratado de Madri de 1750, entre Portugal e Espanha, estabeleceria que a Colônia de Sacramento (hoje em território do Uruguai) seria permutada pelos Sete Povos das Missões, até então ocupados pelos padres jesuítas espanhóis, incorporando ao domínio português mais de um terço do atual território do Rio Grande do Sul (Salgado, 2008, p. 17).

Na costa marítima, a região era desabitada pelos portugueses que nada haviam estabelecido ao sul de Paranaguá até meados do século XVII. As primeiras tentativas de povoamento da região de Laguna datam de final do século XVII. Somente no início do século XVIII, o governador do Rio de Janeiro, D. Francisco de Távora, objetivando uma expansão das conquistas territoriais para o sul elevou à povoação Santo Antonio dos Anjos da Laguna. Ainda, ordenou a João de Magalhães examinar e abrir caminho para o Rio Grande de São Pedro e dali para as campanhas de Buenos Aires devendo o mesmo relatar também o estado em que se encontrava a Colônia de Sacramento.

A partir de 1728, inicia-se um novo povoamento da região de São José do Norte nas imediações de onde surgiria, alguns anos mais tarde, a freguesia de Viamão2. Em 1742, a Vila de Laguna é desmembrada do governo de São Paulo e integrada ao do Rio de Janeiro dando continuidade ao processo de ocupação desta região sul.

Com a fundação da colônia de Sacramento e de Laguna, logo começou o transito entre as duas localidades e pode-se constatar a existência de muito gado selvagem assim como a presença indígena na região, sobretudo os índios charruas e minuanos. Expedições exploratórias sucessivas são empreendidas pelos portugueses na região sul dando início ao comércio do gado, através do caminho do Viamão.

2 Ponto final de parada que daria nome à Rota do Viamão, ou caminho que levava ao Viamão. 


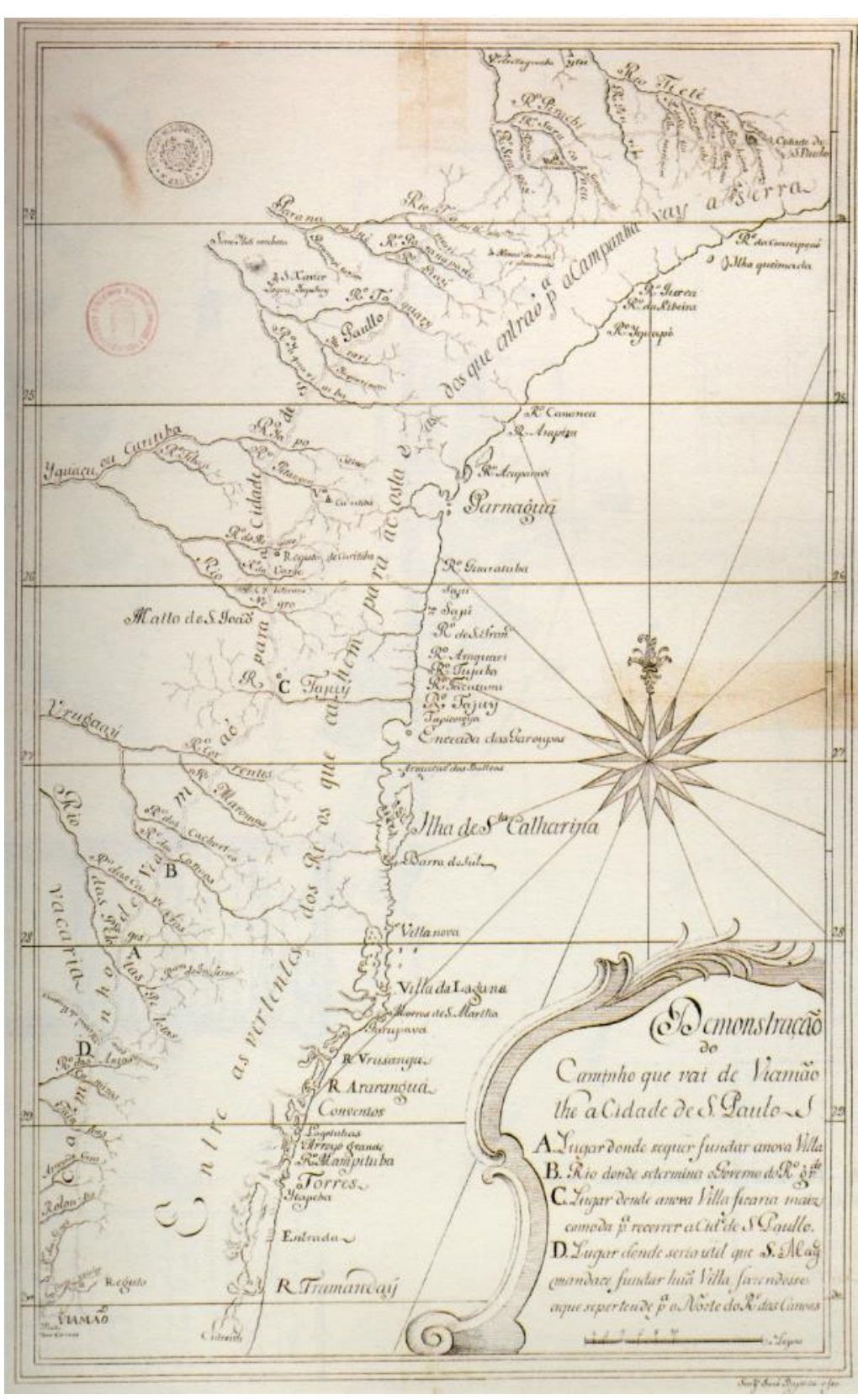

Figura 1. Demonstração do Caminho que vai de Viamão até a cidade de São Paulo. Fonte: Arquivo Histórico Ultramarino, Desenho do Sargento João Baptista, século XVIII.

Na Capitania de São Pedro, a consolidação de uma nova rota do sul ligando os campos de Curitiba e São Paulo tinha por finalidade encurtar os caminhos e evitar os acidentes geográficos existentes na primitiva rota marítima. Em 1731, já começava o tráfego pela nova estrada, o que determinaria a queda da importância de Laguna como entreposto. Nessa época também se iniciaria o povoamento do Porto de Viamão, onde seria fundada posteriormente a cidade de Porto Alegre.

Em 1765, quando o Morgado de Mateus inicia o seu governo da capitania de São Paulo, foi enviado para o Brasil, pelo Marquês de Pombal, Manoel Jorge Gomes Sepúlveda, mais conhecido no Brasil como José Marcelino de Figueiredo, para assumir o Governo da Capitania de Rio Grande de São Pedro, em 1769. Este observou a posição estratégica do porto de Viamão, por estar a meio caminho dos dois pontos fortificados do continente, Rio Grande e Rio Pardo, por vias perfeitamente navegáveis, e teve logo a convicção de que ali é que deveria ser localizada a capital. Assim, em 1772, o Porto dos Casais (futura Porto Alegre) seria desmembrada da jurisdição eclesiástica de Viamão (freguesia de Nossa Senhora da Conceição de Viamão), dando-lhe a nova denominação de São Francisco do Porto dos Casais, denominação efêmera, pois, em 1773 passaria a denominar-se freguesia de Nossa Senhora Madre de Deus de Porto Alegre. Neste mesmo ano, reconhecendo a importância estratégica do lugar, o Vice Rei Marquês de Lavradio, transfere para ela a administração do continente, tornando-a capital (Salgado, 2008, p. 23).

No governo de Morgado de Mateus, o caminho do Viamão se configurou como importante rota de conexão comercial, social e política da rede urbana nas capitanias do Sul, por onde suas ações fortemente se aplicariam no território.

\section{0 governo de Morgado de Mateus}

O poder do Clero ainda dirigia os territórios da colônia sob certos aspectos, porém, as estratégias da Coroa para a dominação do território na segunda metade do século XVIII intencionam racionalidades político-administrativas amplamente utilizadas no que diz respeito a uma estruturação do território, principalmente no quesito militar e de proteção do que já havia sido conquistado por Portugal. A Idade Moderna estava, a partir do século XVIII, sendo refletida também nas Colônias, 
através da formatação de uma nova gestão que, pautada em princípios decorrentes de novas necessidades, tentavam equalizar as tensões que encobriam o território através de novas "políticas de urbanização" (Bellotto, 2007). Ganha força nas Capitanias de São Paulo e do Sul essa nova lógica, a partir da gestão do Morgado de Mateus, enviado por Pombal.

Dom Luís Antônio de Souza Botelho Mourão, o Morgado de Mateus, de formação aristocrática e vasto conhecimento em Engenharia Militar e de Fortificação, foi o Governador Geral e Capitão de São Paulo por dez anos, de 1765 a 1775. Neste período, destaca-se o grande impulso à urbanização e à regularidade do traçado urbano, como descreve Maria Fernanda Derntl: "a ação extensa dos engenheiros militares e o estabelecimento de determinações formais em cartas régias, são consideradas fundamentais na imposição dessa política" (2010, p.9).

Permeando as ações e incumbências do Governo de Morgado de Mateus, o alinhamento com a política Pombalina se estendeu à Capitania de São Paulo através de duas Cartas régias de 26 de janeiro de 1765 (DERNTL, 2010, p.58, 59), em que se explicitava a necessidade do combate aos espanhóis, fortificação nas fronteiras, negociação com os jesuítas segundo o tratado de Madri (1750) - que culminaria na sua retirada - incorporação e exploração dos indígenas, também com a conversão de aldeamentos em vilas, reativação da economia e fortalecimento do poder central.

As necessidades de fortificações pareciam, ao governador, muito grandes, ante a já vasta política de proteção contra iminentes invasões espanholas. A política de proteção do território estabelecida por este governador era amparada e garantida através da fundação de povoações (freguesias e vilas).

A população da Capitania de São Paulo estava, segundo Bellotto (2007, p.172) dispersa pelo comércio e pela prática da lavoura itinerante, pois as atividades econômicas na capitania não tinham um caráter sedentário, ao contrário dos engenhos de açúcar e da mineração, que propiciaram o povoamento em outras regiões do Brasil.

O eixo do Viamão, servia assim, para o transito das tropas de gado que abasteciam as minas e outras regiões da Colônia. Na administração de Morgado de Mateus, este foi considerado um eixo preferencial para a urbanização (Derntl, 2010, p.84).

A rede urbana das capitanias do Sul, assumida pela governança de Morgado de Mateus, tinha como ponto focal a cidade de São Paulo, com destaque para a Vila de Nossa Senhora da Ponte de Sorocaba ${ }^{3}$ como sendo uma das mais populosas, entorno das quais se alojavam aldeamentos indígenas e freguesias em potencial, muitas delas elevadas a vila segundo as estratégias de sua administração. As freguesias existentes no início de sua administração eram excessivamente grandes, demonstrando a necessidade de reestruturação do território para obter um maior controle das terras da Coroa.

Dentro dessa lógica de estruturação do território, dez vilas segundo Derntl (2010, p.71), foram fundadas na Capitania de São Paulo na gestão de dom Luís Antônio de Souza Botelho Mourão. Entre elas, a freguesia de Itapeva da Faxina que foi elevada a vila em 1769 e as freguesias de Itapetininga e Apiaí em 1771, desmembradas do termo da Vila de Nossa Senhora da Ponte de Sorocaba, numa estratégia de controle ao sul da capitania, ao longo do Caminho do Viamão.

Numa política de defesa do território e de povoações o Morgado de Mateus empreendeu ações nas diferentes direções do território. Ao sul, onde serão encontrados nossos objetos de estudo, empreende a defesa e colonização do caminho do Viamão na rota terrestre para as expedições militares que iam combater os espanhóis no Rio Grande. Promove também uma ocupação dos sertões do Tibagi e dos Campos de Guarapuava. Nesta direção, podem ser destacadas as seguintes povoações: Faxina, atual Itapeva [SP]; Itapetininga, atual Itapetininga [SP]; Santo Antonio das Minas do Piaí ou Apiaí, atual Apiaí [SP]; Santo Antonio do Registro, atual Lapa [PR]; Nossa Senhora dos Prazeres de Lages, atual Lages - SC; Santa Ana do Ipó, atual Castro [PR]. Ainda, no litoral: Araripa, localidade próxima a Cananéia [SP]; Vila Nova de São Luis de Guaratuba, atual Guaratuba [PR]; Sabaúna, bairro de Cananéia [SP] (Salgado, 2008, p.27).

\footnotetext{
${ }^{3}$ Bellotto, Heloísa Liberalli, op. cit, .p. 175.
} 
A rede urbana que o Morgado de Mateus encontrou tinha como aglomerado principal a cidade de São Paulo, em torno da qual gravitavam aldeamentos indígenas e freguesias. Para o Oeste, destacavam-se as vilas de Sorocaba e Itu.

Para o sul, além de Sorocaba, na serra-acima, o que havia de considerável em matéria de povoação era só a vila de Curitiba, que fora criada no século XVII em torno da exploração de ouro e do Registro de Curitiba. $\mathrm{O}$ alvo do Morgado de Mateus eram os Campos de Lages, os últimos confins que na época possuía a capitania de São Paulo na sua parte sul, e que se estendia até as margens do Rio das Pelotas. Com o mesmo objetivo, de colonização do roteiro do sul, providenciara, em julho, o povoamento de Faxina; punha grandes esperanças na fundação desta povoação, confiando nos bons serviços de seu diretor.

A principal dificuldade no projeto de implantação de povoações ao sul era a questão de soberania territorial. Se os limites da vila de Curitiba para o sul eram até o rio Pelotas, que dividia o Campo das Lages do Campo de Vacaria, o território era incontestavelmente paulista. Mas, no dizer do então governador do Rio Grande, José Custódio de Sá e Faria, tanto Lages como Iguatemy significavam pretensões ilegais de D. Luís Antonio, uma vez que se situavam em território "seu", no primeiro caso e espanhol no segundo.

De qualquer modo, em Lages, com a povoação prosperando pouco a pouco, estava lançada a ponta de lança na direção sul visando facilitar a extensão dos domínios portugueses. Assim, na fundação de Lages o objetivo militar (trânsito de tropas) mesclava-se ao colonizador (implantação de povoações) e ao político (extensão de domínio português). Entretanto, sofria o Morgado de Mateus com este plano a primeira contestação de vulto, por parte de autoridades locais: José Custódio de Sá e Faria e o Conde da Cunha.

Ainda, o Morgado de Mateus manifestava pretender fundar Faxina no caminho entre São Paulo e Curitiba, por considerar o local uma paragem acomodada para pouso dos comerciantes de Viamão. Como Faxina, hoje Itapeva [SP], situava-se à margem da estrada para o Rio Grande, beneficiava-se das duas rotas - a do Viamão e a do Tibagí. As mesmas preocupações do Morgado se referem a Itapetininga, onde fizera freguesia, por ficar muito distante de Apiaí e, portanto, sem assistência religiosa.

A colonização da Costa Atlântica também seria um objetivo de Morgado de Mateus na sua política de ocupação da parte sul do território. Para tal, através de Santo Antônio das Minas do Apiaí, situada na convergência do antigo caminho do Peabiru com o vale do Ribeira do Iguape, iniciouse a colonização da parte marítima entre Curitiba e a cidade de São Paulo.

No percurso da rota do Viamão, que ligava São Paulo ao sul dos domínios portugueses, passando por Curitiba, o Morgado de Mateus fundaria, portanto: Itapetininga [SP], Faxina, atual Itapeva [SP], Santo Antonio das Minas do Apiaí, atual Apiaí [SP] - nossos três objetos de estudo -, e também Santa Ana do Ipó, atual Castro [PR], Santo Antonio da Lapa, atual Lapa [PR] e Nossa Senhora dos Prazeres de Lages, atual Lages [SC]. Consolida-se, assim, a Estrada do Viamão, entre a capital paulista e o Rio Grande de São Pedro até a colônia do Sacramento, atingindo os interesses de defesa militar do sul e da pecuária dos Campos de Vacaria.

Santo Antonio de Apiaí, que em 1735 era a Freguesia de Santo Antonio das Minas, também foi elevada a vila por D. Luís Antonio em 14 de agosto de 1771. Embora já bastante exploradas, suas jazidas ainda produziam algum ouro, justificando a existência da vila.

Também a sudoeste de Sorocaba, em meio caminho para a região do Tibagi, situava-se a povoação de Itapetininga fundada em 1766, por Simão Barbosa Franco. A elevação a vila foi ordenada por D. Luís Antonio, em outubro de 1770. A nova vila, muito próxima a Sorocaba, preenchia as mesmas condições de Faxina: possuir povoamento e colonização na área de passagem para o Tibagi, que era ainda muito despovoada.

\subsection{A regularidade das fundações urbanas}


Quando se analisam plantas oficiais de vilas formadas na Colônia portuguesa nas Américas, na segunda metade do século XVIII, pode-se estabelecer relações de similaridade quanto à motivação, implantação, traçado e equipamentos.

Segundo Teixeira e Valla (1999), o século XVIII reverberou a implantação de um urbanismo Iluminista no Brasil, sobre exemplos de assentamentos Jesuítas que vão, desde a Amazônia, até vilas como Aldeia Maria em Goiás (1782) e Sant'Ana (1775), onde a política pombalina teve grande aplicação. Também é possível identificar exemplos de planos urbanos regulares setecentistas para outras vilas, como o de Viçosa (1769), Portalegre (1772) e Macapá (1752). 0 exemplo da planta da Vila de Alcobaça na capitania de Porto Seguro, de 1774, revela a implantação regular, que estabelece relações de cheios e vazios para a praça da matriz e para o espaço distinto do pelourinho, caracterizando a distinção de funções (Figura 2).

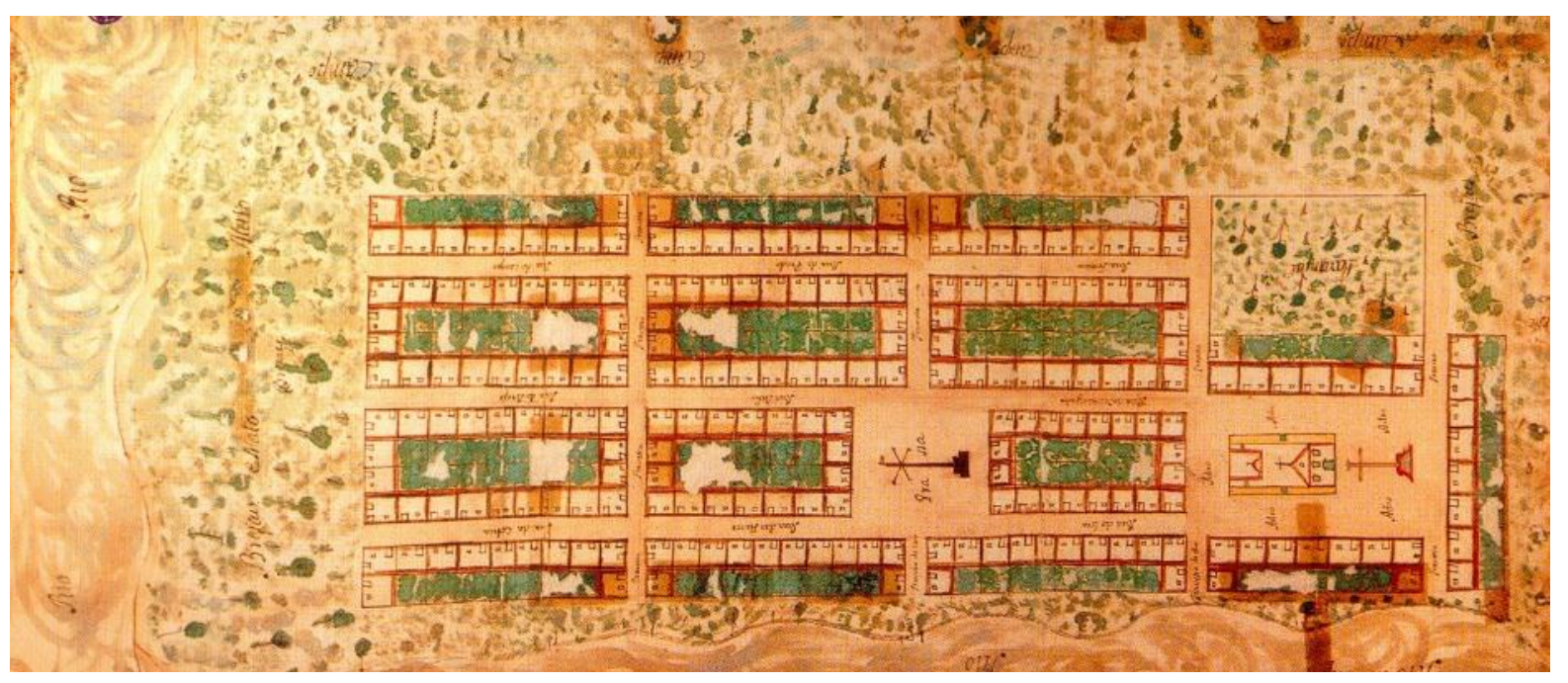

Figura 2. Planta da Vila de Alcobaça, na Capitania de Porto Seguro, 1774, implantação regular que estabelece relações de cheios e vazios para a praça da matriz (à direita) e para a praça do pelourinho (à esquerda).

Fonte: Teixeira; Valla, 1999, p.279.

A praça como elemento central e estruturador da malha urbana e os conceitos de planejamento advindo das práticas coloniais, aliadas à posição de ruas e edifícios da ordem civil, permitem que a quadrícula ortogonal se aplique, fazendo do traçado geométrico das cidades citadas acima, uma recorrência; assim como das vilas elevadas sob a administração do Morgado de Mateus na Capitania de São Paulo durante sua gestão (1765-1775). Este traçado geométrico pode ser observado enquanto dado de morfologia, nos nossos objetos de estudo: as vilas de Itapeva, Itapetininga e Apiaí.

Outros exemplos também podem ser observados como o estabelecimento da fortaleza de Nossa Senhora dos Pazeres do Iguatemy (1770), pelo Morgado de Mateus em região ocupada após a descoberta das minas de Cuiabá - hoje no município ao lado de Amambaí, Mato Grosso, divisa com o Paraguai - foi, segundo Salgado e Pereira (2014, p.5) uma instalação militar, "criada para proteger os acessos fluviais às áreas de mineração". A Fortificação de implantação Renascentista, sob uma nova perspectiva militar, demonstra um traçado ortogonal, com a praça como centro aglutinador e estruturador da vila (Salgado \& Pereira, 2014, p.5).

O processo de fundação da Villa dos Prazeres de Nossa Senhora do Iguatemy também é revelador da manutenção da tradição do governo português na fundação de cidades na sua colônia; assim como do papel dos quadros técnicos no processo de demarcação de suas fronteiras. As atividades de demarcação da fronteira com os espanhóis, na Capitania de São Paulo, contava com quadros técnicos de alto nível, responsáveis pela elaboração dos planos de construção de suas vilas, edifícios e fortificações, como foi o caso de José Custódio de Sá e Faria4, que elaborou a planta da então Praça de Nossa dos Prazeres do Iguatemy (Figura 3).

4 Engenheiro militar português fazia parte da equipe enviada para o Brasil para apoiar as atividades de demarcação decorrentes do Tratado de Madrid de1750. Trabalhou no Rio de Janeiro, no Rio Grande do Sul, em Santa Catarina e em São Paulo. Em 1774, foi designado pelo Morgado de Mateus para organizar o sistema defensivo na Praça de Iguatemi. (Reis Filho, 2000, p. 245) 


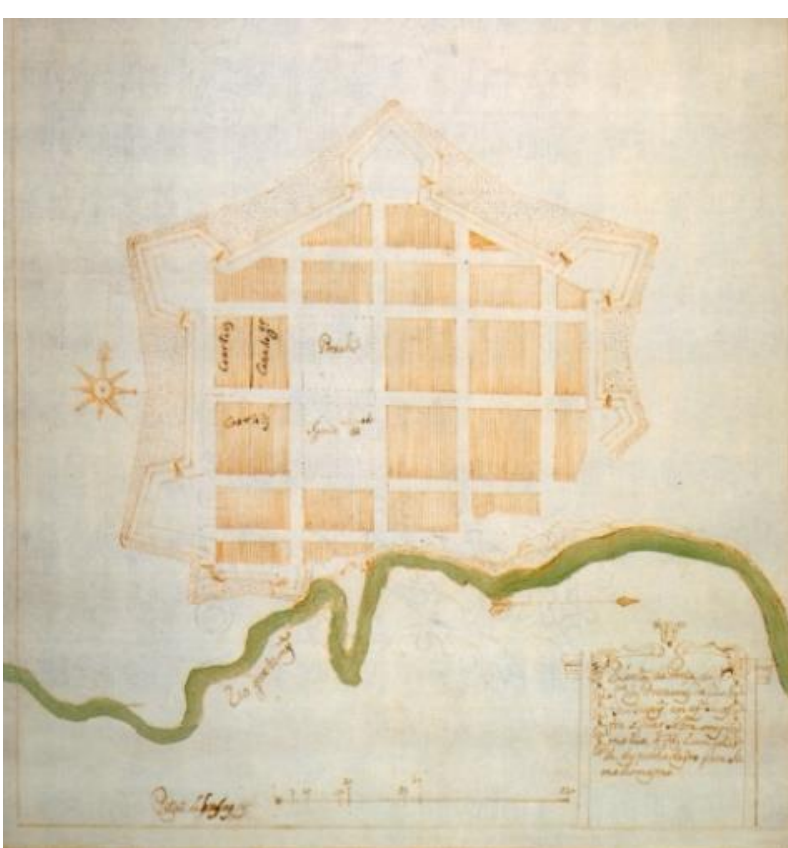

Figura 3. Planta da Praça de Nossa Senhora dos Prazeres do Rio Guatemy. Original da Biblioteca Nacional do Rio de Janeiro, 1769. Fonte: Nestor Goulart Reis Filho. Imagens de vilas e cidades do Brasil Colonial. Edusp; Imprensa Oficial do caminho do Viamão. (Salgado, 2008, p.31). Estado de São Paulo; Fapesp. São Paulo, 2000, p.245.

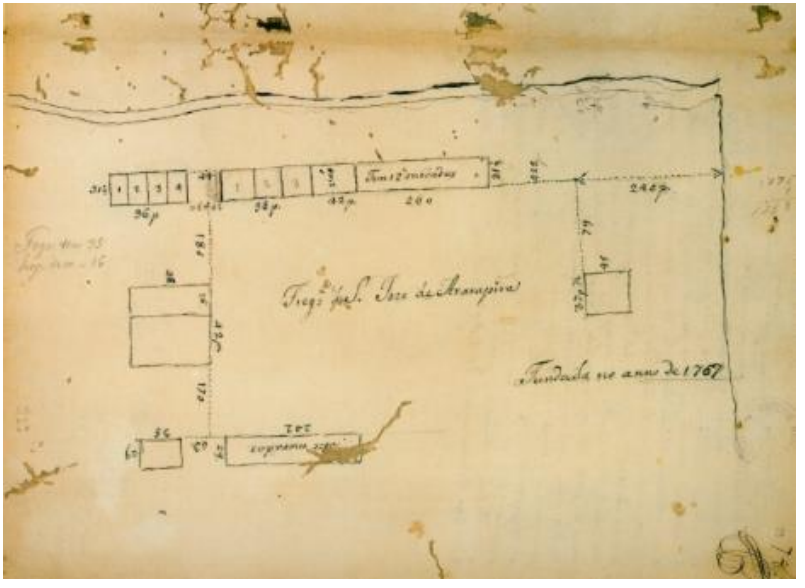

Figura 4. Freguesia de São Jose de Araripa.

Fonte: Arquivo Histórico do Itamarati. Original de José Custódio de Sá e Faria de 1776.
Em janeiro de 17765, José Custódio de Sá e Faria fez uma viagem de Santos a Paranaguá e ao rio de São Francisco do Sul, nas divisas da capitania de São Paulo com a de Santa Catarina. Durante a viagem realizou observações e levantamentos em todas as povoações percorridas. Dos desenhos, que revelam a política de regularidade dos traçados urbanos, conservam-se apenas os que estão contidos no diário, como São José de Ararapira (Figura 4) que foi fundada em 1767 e elevada à freguesia em $1769 \mathrm{e}$, pouco depois exaustorada. São José de Ararapira situava-se à margem direita do rio Ararapira, em território do município de Cananéia [SP]. Sua população era constituída por índios de uma antiga aldeia e por moradores das áreas rurais mais próximas.

A Vila de Nossa Senhora de Conceição da Lage (Figura 5), registra na área central o núcleo de seu povoamento. No primeiro ano de governo do Morgado de Mateus, a fundação de Lages se inseria nas tentativas de estabelecer povoações na direção sul, visando fixar o povoamento ao longo do

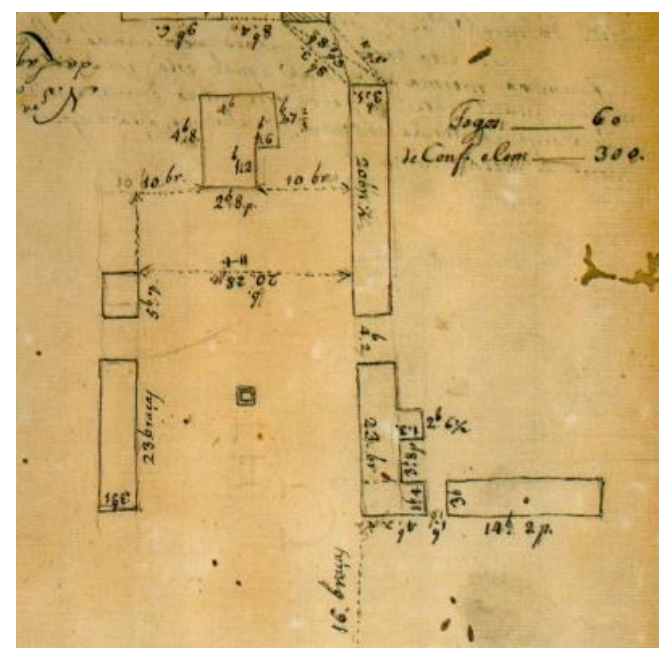

Figura 5. Nossa Senhora da Conceição da Lage. Fonte: Arquivo Histórico do Itamarati. Original de José Custódio de Sá e Faria de 1776.

\section{Metodologia de estudo da morfologia urbana}

Para a interpretação da morfologia urbana das cidades em estudo foram analisados aspectos da fundação destes núcleos urbanos, de acordo com a metodologia empregada pelo HPIP6 (Heritage of Portuguese Influence Portal), coordenado, entre outros por Renata Malcher de Araújo.

Analisamos três figuras de satélite contemporâneas das cidades fundadas no século XVIII: Apiaí, Itapeva e Itapetininga, no contexto da política urbanizadora do Morgado de Mateus na ocupação

\footnotetext{
${ }^{5}$ Reis, Nestor Goulart. Imagens de Vilas e Cidades do Brasil Colonial, (colaboradores Beatriz Piccolotto Siqueira Bueno, Paulo Júlio Valentim Bruna), Editora da Universidade de São Paulo; Imprensa Oficial do Estado de São Paulo; Fapesp, 2000.
} 
do sul da capitania de São Paulo, ao longo do Caminho do Viamão. Para a realização da análise comparativa, a cartografia histórica e os mapas atuais foram interpretados de acordo com seus traçados viários, edifícios que conformavam a centralidade da vila colonial, a matriz e a casa de câmara e cadeia com o seu pelourinho, em busca dos elementos estruturais e formais relativos ao tecido urbano procurando identificar permanências e rupturas relativas à implantação original destas cidades. Para tanto, fez-se uso dos softwares gráficos Photoshop ${ }^{\circledR}$ e CorelDraw ${ }^{\circledR}$.

A fim de evidenciar as permanências e rupturas da morfologia urbana do século XVIII para o XXI, destacou-se na cartografia histórica e nos mapas: (1) as ruas em polilinhas coloridas, (2) os edifícios em polígonos policromáticos, (3) as praças, (4) nomenclatura original das ruas quando existentes, (5) nomenclatura atual das ruas e (6) direções e sentidos. Nesta análise pode-se observar a disposição dos edifícios públicos (Casa de Câmara e Cadeia, Pelourinho) e religiosos (Igreja Matriz, Cruzeiro) do período de fundação das vilas, junto à suas praças; organizando a trama de vias, e as alterações formais sofridas no decorrer dos séculos, assim como o forte crescimento das cidades a partir desses núcleos originários.

\subsection{Morfologia urbana de Apiaí, Itapetininga e Itapeva}

\subsubsection{A Vila de Apiaí}

Em Apiaí existem dois ribeirões de nome Água Limpa, um deles na face Sul do morro denominado "Morro do Ouro". Ao longo dele, aos pés do morro, nasceu o primeiro assentamento de Apiaí, conhecido como "Pião". Esse assentamento, de capela constituída, como nos conta Luz (1996, p. 39-40), perdurou até a metade do século XVII, com a exploração do Morro do Ouro estritamente por parte da coroa.

Com a redução da produção do ouro no assentamento do "Pião", a população migrou e se juntou a outro núcleo formado em torno da capela de São Benedito, local hoje denominado de Vila Velha. Os vestígios deste segundo assentamento podiam ser constatados até os anos de 1950 através de ruínas, que se localizam hoje no bairro de Cordeirópolis. Foi nesse lugar que a partir da instauração do quinto, pelo Rei D. Fillipe II, se estabeleceu a casa do Registro.

Segundo Luz, o povoado de Apiaí, já nas primeiras décadas do século XVIII, vinha chamando a atenção dos governadores. Primeiro o governador capitão mor Antônio da Silva Caldeira Pimentel (1727-1732) e depois Antônio Luís de Távora, o Conde de Sarzedas que, assumindo a direção da capitania, estendiam seus olhares para a produção do ouro de Apiaí, sem descuidar do recebimento dos devidos impostos. (Luz, 1996, p.30).

Nestor Goulart Reis (2013, p.101), também demonstra a importância da mineração em Apiaí, no contexto de extração do ouro nos territórios da Repartição Sul da colônia. No início do século XVII, Apiaí já se constituía como importante núcleo de extração do ouro e ganhava as atenções da Coroa Portuguesa.

Como ponto participante da rota do Viamão, a Freguesia de Apiaí que ficava na rota que descia a Sudeste de Itapeva, constituía ponto focal e estratégico na lógica administrativa de Morgado de Mateus. Assim, a 14 de agosto de 1771, por ordem deste governador da Capitania de São Paulo, D. Luís Antônio de Souza Botelho Mourão, a freguesia foi elevada a vila, no contexto de uma política de formação de uma rede de freguesias e vilas no território da capitania:

Porquanto S. Mage que Deos gde foi servido ordenar-me nas Instruções de vinte e seis de Janeiro de mil setecentos e sessenta e cinco e em outras ordens que ao depois fui recebendo, que era muito conveniente ao seu Real serviço que nesta Capitania se erigissem Villas naquelas partes que fossem mais convenientes, e que a ellas se congregassem todos os vadios e dispersos, ou que morem em citios volantes, para morarem em Povoações civil em que se lhes pudessem administrar os sacramentos e estivesem promptos para as ocasiões do seu Real serviço; e porquanto me consta que a povoação de Piahy hé lugar acomodado para se levantar em Villa porque se acha em grande distancia de Villas que tenhão justiças e não podem estas satisfazer as suas obrigações, seguindo-se todos aqueles inconvenientes 
que desta falta, costumão seguir aos Povos. (Carta de D. Luiz Antônio de Souza Botelho Mourão ao diretor do povoado, apud. Luz, 1996, p.30). (grifo nosso).

Nesta ordem, o governador ordenava fundar a vila levantando pelourinho e formando seu termo:

[...] ordeno ao Sargento Mor Custodio Francisco Pereira que junto com o Official de mayor posto que houver naquele continente, fação erigir em Villa a dita Povoação levantandolhe pelourinho e signalando-Ihe termo, e assim nomearão as pessoas mais capases para Juizes, Vereadores, Procurador do Conselho e Escrivão, que com a nomeação dos ditos se recorrerá á secretaria deste Governo para se lhes passar Provisão. O que tudo obrarão conforme aqui determino, que he o mesmo que me facultão as ordens de S. Magestade acima apontadas. São Paulo a quatorze de Agosto de mil setecentos e setenta e um. (Carta de D. Luiz Antônio de Souza Botelho Mourão ao diretor do povoado, apud. Luz, 1996, p. 30). (grifo nosso).

Uma terceira fixação do povoado se deu em 1797 em local conhecido como Paiolinho. A igreja matriz era dedicada a Santo Antônio e em sua praça fronteiriça foi fundado o pelourinho e então, demarcado o rocio e local de fundação da casa de câmara e cadeia. Quando elevada a Vila de Santo Antonio das Minas de Apiahy, em 14 de Agosto de 1771, seu termo congregava os arraiais de Iporanga e Capela do Ribeira (Luz, 1996, p.31).

$\mathrm{Na}$ análise do núcleo fundacional de Apiaí (Figura 6), utilizando um mapa de 1949, que ainda guardava a configuração inicial da vila e uma imagem de satélite atual, é possível observar permanências e rupturas na morfologia urbana da vila fundada em 1771. São elas: a permanência das mesmas ruas do período de fundação: (em linha vermelha), a Estrada Geral do Sul, hoje Av. Duque de Caxias, que corta a cidade de Norte a Sul; a Rua Dezenove de novembro é a mesma de 1949 (em linha laranja). Pode-se observar a Igreja Matriz de Santo Antônio (cruz vermelha), com a Cadeia de 1912 ao lado, na localização original da antiga Casa de Câmara e Cadeia (em quadrado

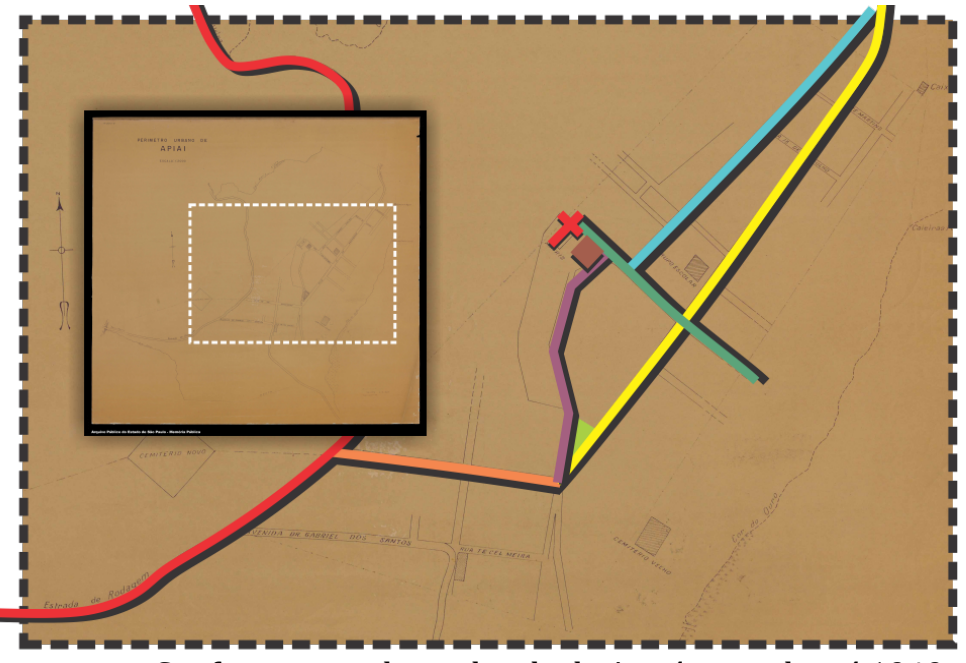

Figura 6. Configuração urbana da vila de Apiaí mantida até 1949. Fonte: Arquivo do Estado de São Paulo. marrom), na mesma Rua Sete de Setembro do mapa antigo. A Rua Quinze de Novembro continuou como eixo de expansão da vila, como se pode observar na imagem atual (Figura 7).

Devido à peculiaridade da vila montanhosa se localizar em área de Serra, adaptou-se o traçado ortogonal para esta topografia, culminando em uma racionalidade de espaço também recorrente em plantas de cidades coloniais. A praça da matriz (em polígono verde, na Figura 7) confunde-se meio ao adensamento da cidade. Ressalva-se que a atual Igreja Matriz não é a mesma da fundação (Figura 8), mudando a direção de sua posição, porém localizando-se no mesmo espaço. Os anos que seguiram após a fundação da vila garantiram trocas sociais, econômicas e culturais que permitiram o crescimento urbano com a preservação das características coloniais na sua morfologia urbana.

A paróquia de Santo Antônio de Apiaí inicialmente se estabeleceu na primeira formação do povoado, junto ao Pião supracitado na tipologia construtiva usual da taipa. A segunda ficava junto à atual casa paroquial de Apiaí, onde se conserva resquícios de seu muro original. A igreja Matriz da Vila de Apiaí (Figura 8) foi fundada na gestão do padre Cláudio Furquim Pedroso de Alvarenga, que regeu até 1779 , sendo sua construção iniciada com a elevação da vila no ano de 1771 . Também feita de taipa, teve sua demolição na década de 1960, mantendo-se sua estrutura até a conclusão da nova Matriz de Apiaí. 


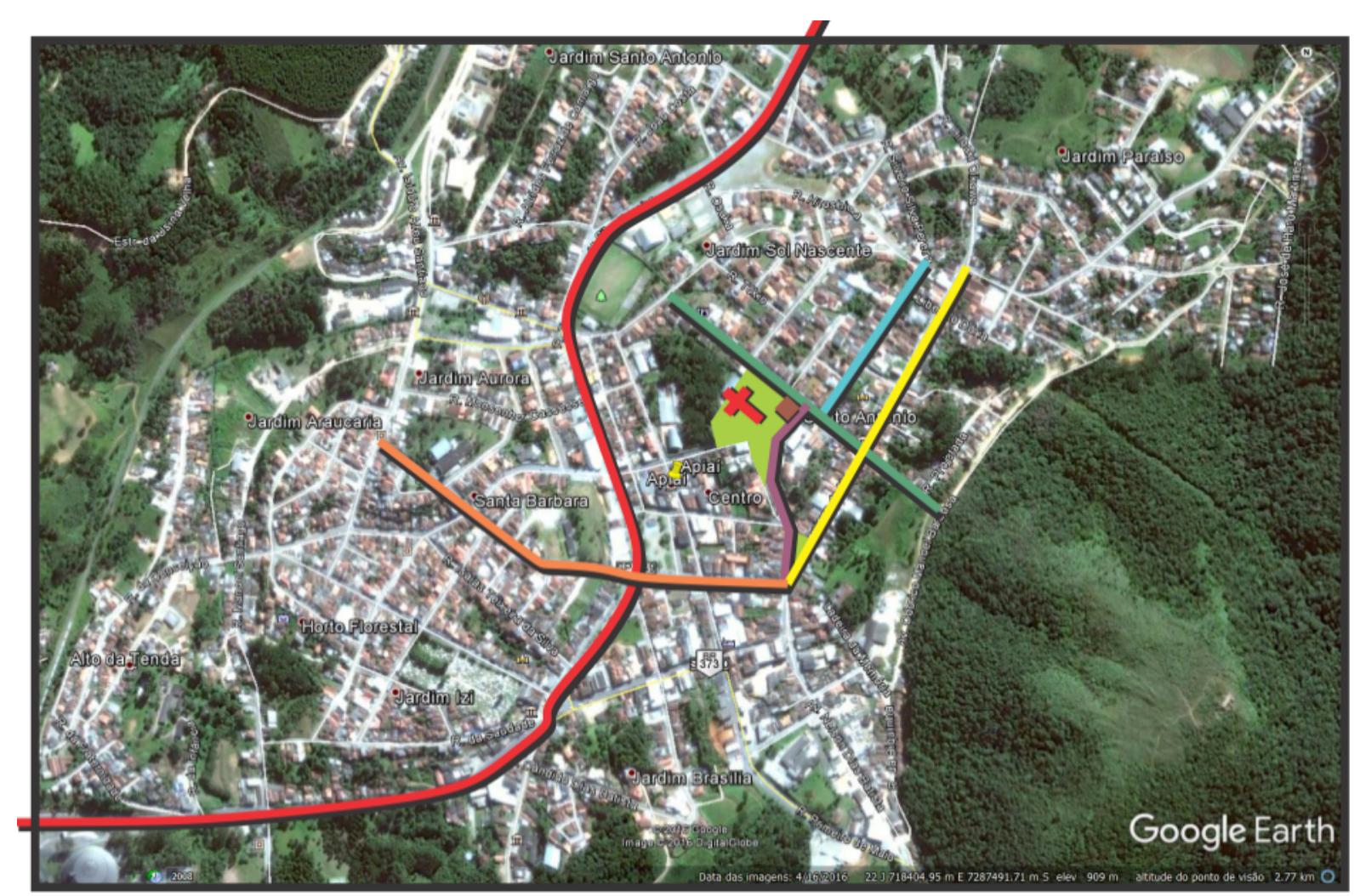

Figura 7. Análise das permanências e rupturas da morfologia urbana original de Apiaí na cartografia contemporânea. Fontes: Arquivo do Estado de São Paulo e imagem de satélite de Apiaí do GoogleMaps®, 2017.
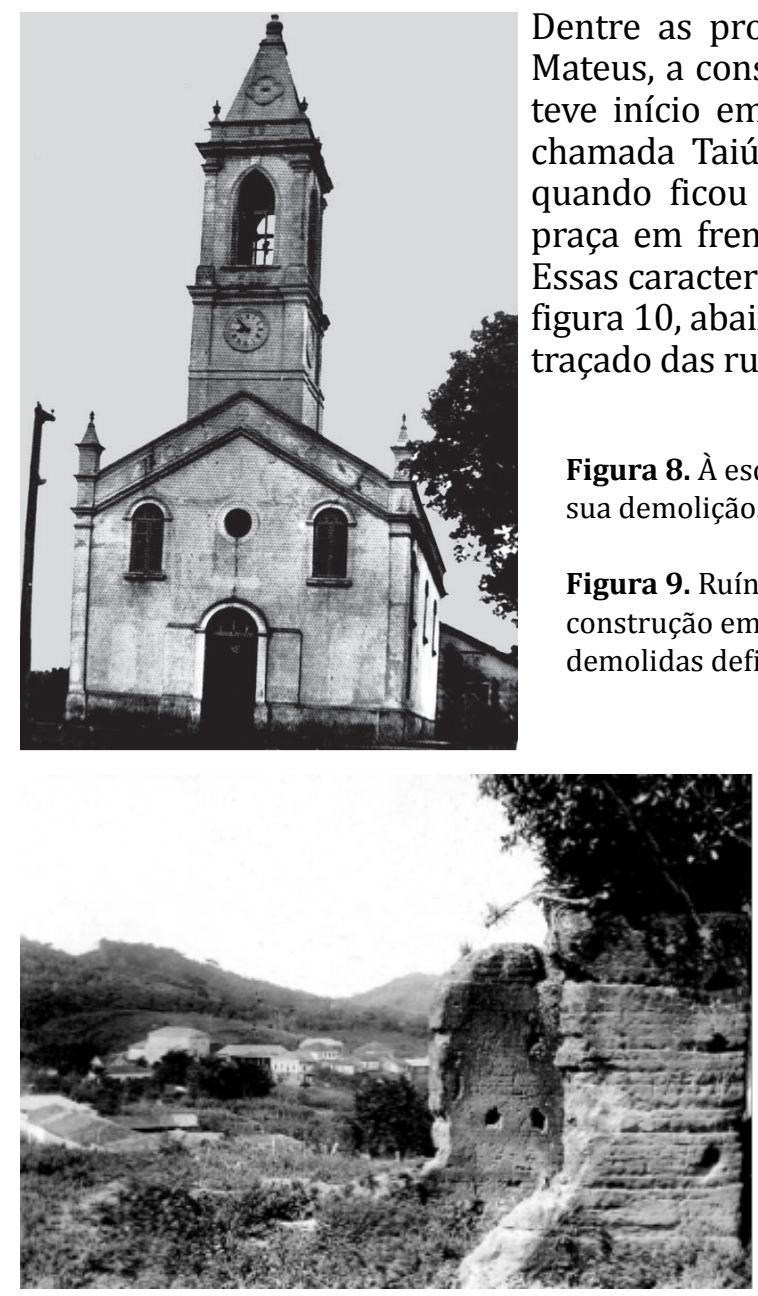

Dentre as providências que seguiam as ordens de Morgado de Mateus, a construção da primeira casa de câmara e cadeia da vila teve início em 1773, feita de taipa de pilão com madeira de lei chamada Taiúva (Figura 9). Ela foi desativada no ano de 1912, quando ficou pronto o novo fórum delegacia e cadeia, hoje na praça em frente à matriz (quadrado marrom nas Figuras 6 e 7). Essas características formais podem ser claramente observadas na figura 10, abaixo, em uma foto aérea da vila, já no século XX, onde o traçado das ruas e a igreja com a cadeia ficam em destaque.

Figura 8. À esquerda, a Igreja Matriz de Apiaí, 1954, poucos anos antes de sua demolição. Fonte: Luz, 1996, p.199.

Figura 9. Ruínas da Cadeia de Apiaí em 1952, com os vestígios da construção em taipa de pilão (abaixo, 9a e 9b). Estas ruínas foram demolidas definitivamente em 1952. Fonte: Luz (1996, p. 97).

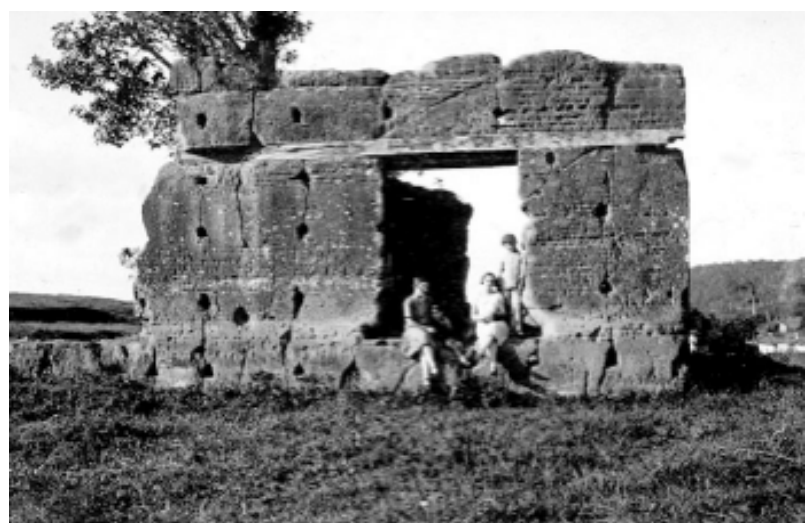




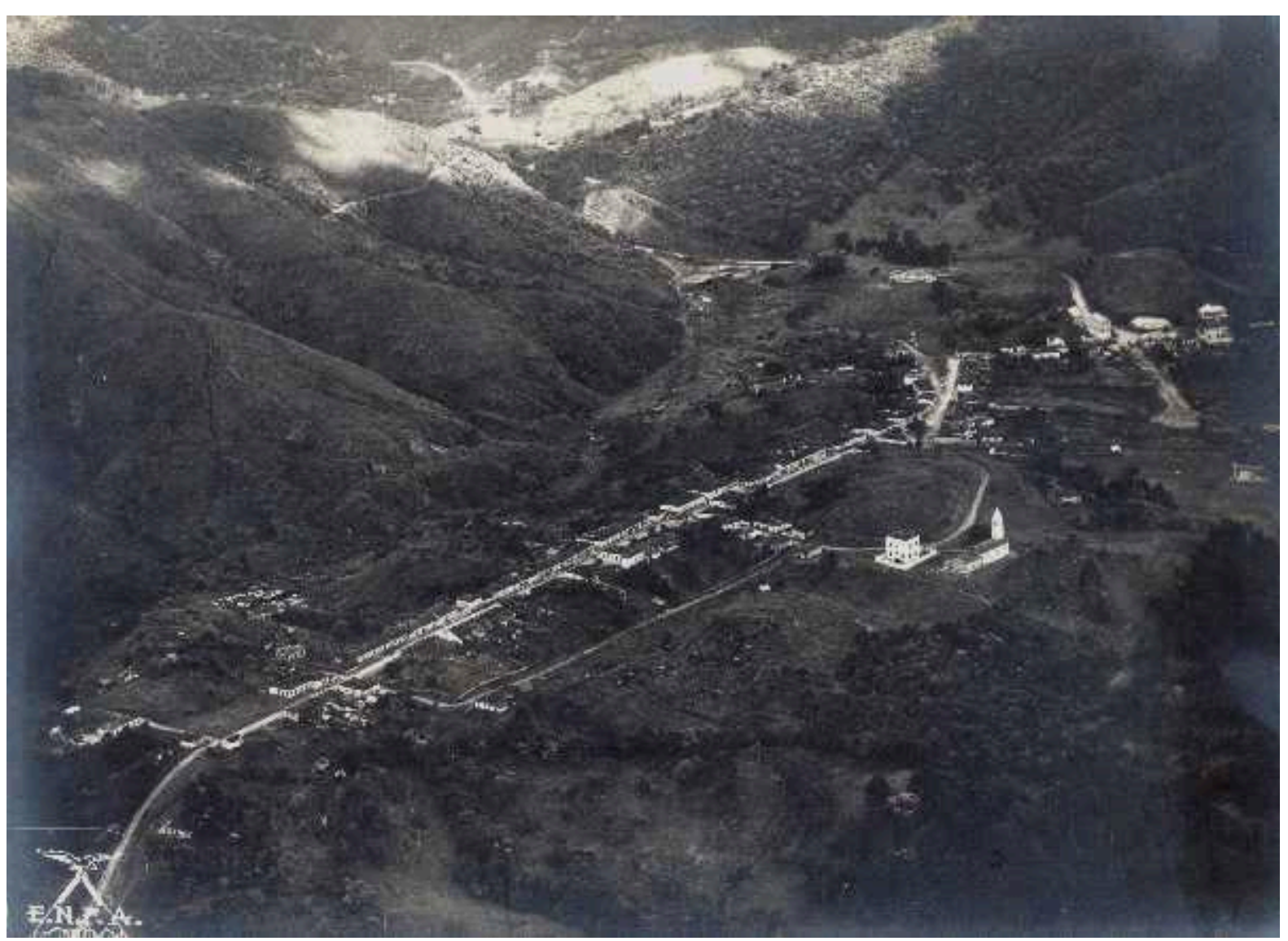

Figura 10. Foto aérea de Apiaí, 1938. Fonte: Luz, 1996, p. 149.

Quando fundou-se a vila de Apiaí, foram postos em uso pela câmara os livros de arrematações, o livro das posses dos funcionários da câmara, o livro do Juiz Presidente, o livro das correições, o livro das despesas da câmara e por fim, a encargo do Sargento Mor, Custodio Francisco Pereira, mandou-se erigir o pelourinho à frente da igreja matriz, hoje na praça Francisco Xavier da Rocha. Bem como demarcar o Rocio, que trazia o núcleo fundacional da cidade para onde hoje conhecemos como o largo da Igreja de Santo Antônio.

Segundo revisão bibliográfica, evidenciam-se quatro hipóteses para a figura do fundador de Apiaí. A primeira atribui sua fundação aos irmãos Domingos e Antônio Rodrigues da Cunha, que primeiro estiveram na região aos anos de 1655 , em função de trabalhos de garimpo nas noticiadas minas do então Governador, Antônio da Silva Caldeira Pimentel. A segunda hipótese é de que Anna Marta Duarte, possuidora de extensas sesmarias, por doar porção de terra relativa à área do Paiolinho juntamente com a imagem do santo à que se dedica a Matriz da vila, teria sido a fundadora. Outra hipótese aponta para o tenente coronel Custódio Francisco Pereira, que seguindo as ordens de Morgado de Mateus, comandou a elevação da Freguesia a Vila, pois, como nos conta Luz (1996, pp.57-58), em 1797 os componentes da Câmara pediram em ofício ao governador, para que reconhecesse Custódio Francisco Pereira como "fundador e criador, pessoa principal desta Villa". Ele foi quem propiciou a organização político-administrativa da vila, sendo o juiz presidente da primeira câmara. A quarta hipótese aponta para Francisco Xavier da Rocha. Capitão Mor e pioneiro na ocupação do Pião, aparece em todas as três fixações do assentamento de Apiaí. Xavier da Rocha foi o nome mais consagrado como fundador por uma tradição oral mantida na cidade, como nos relata ainda o autor e pela bibliografia do início do século XX, sem base documental segura e já superada. (Luz, 1996, pp.55-60).

Fato é que D. Luis Antônio de Souza Botelho Mourão, o Morgado de Mateus, faz uso em sua gestão de um processo de políticas reestruturadoras, dentro de uma perspectiva de proteção dos territórios da Coroa e de fortalecimento da fiscalização de impostos. Assim, de acordo com a própria carta de D. Luiz Antônio de Souza Botelho Mourão ao diretor do povoado e de sua gestão, amplamente estudada por autores como Beatriz Piccolotto Siqueira Bueno (2009), pode-se constatar que as vilas erigidas no seu governo têm fundação atrelada a uma lógica administrativa regional própria. 


\subsubsection{A Vila de Itapetininga}

Dentro do contexto do primeiro ciclo de exploração do ouro nas minas do Sul, a freguesia de Nossa Senhora dos Prazeres de Itapetininga ganhou destaque, também a Sudoeste, porém, mais próxima de Sorocaba. Até meados do século XVIII, após a transferência da capital da colônia para o Rio de Janeiro, a mineração já atingia seu mais alto nível. As produções, significativas para a metrópole, já decresciam na região das Capitanias do Sul e iniciava-se o processo da região das minas gerais. 0 transporte do gado através do caminho do Viamão possibilitou destaque também para o pouso a beira do Rio Itapetininga. Bandeirantes, tropeiros e comerciantes de animais utilizavam a parada para abastecimento e pouso, viabilizando importantes trocas sociais e econômicas. Foi em meados de 1750 que a povoação de Itapetininga se destacou. Segundo Bonadio (1934, p.33), a ocupação linear entre Sorocaba e Itapetininga era intensa, com a sedentarização de contingentes populacionais para fins de transações comerciais das mulas e seus suprimentos.

No ano de 1771, foi erigida a Nova Vila de Nossa Senhora dos Prazeres de Itapetininga, sob a gestão do Morgado de Mateus, sendo a freguesia desmembrada do território da Vila de Nossa Senhora da Ponte de Sorocaba. 0 rápido crescimento do povoado com a circulação da mercadoria - o gado permitiu a implantação e crescimento da cidade em uma quadrícula ortogonal.

$\mathrm{Na}$ análise morfológica de Itapetininga, utilizamos a cartografia de 1886 (Figura 11) do núcleo fundacional da cidade de Itapetininga e o mapa de satélite de 2017, retirado do site GoogleEarth ${ }^{\circledR}$, da mesma área (Figura 12).

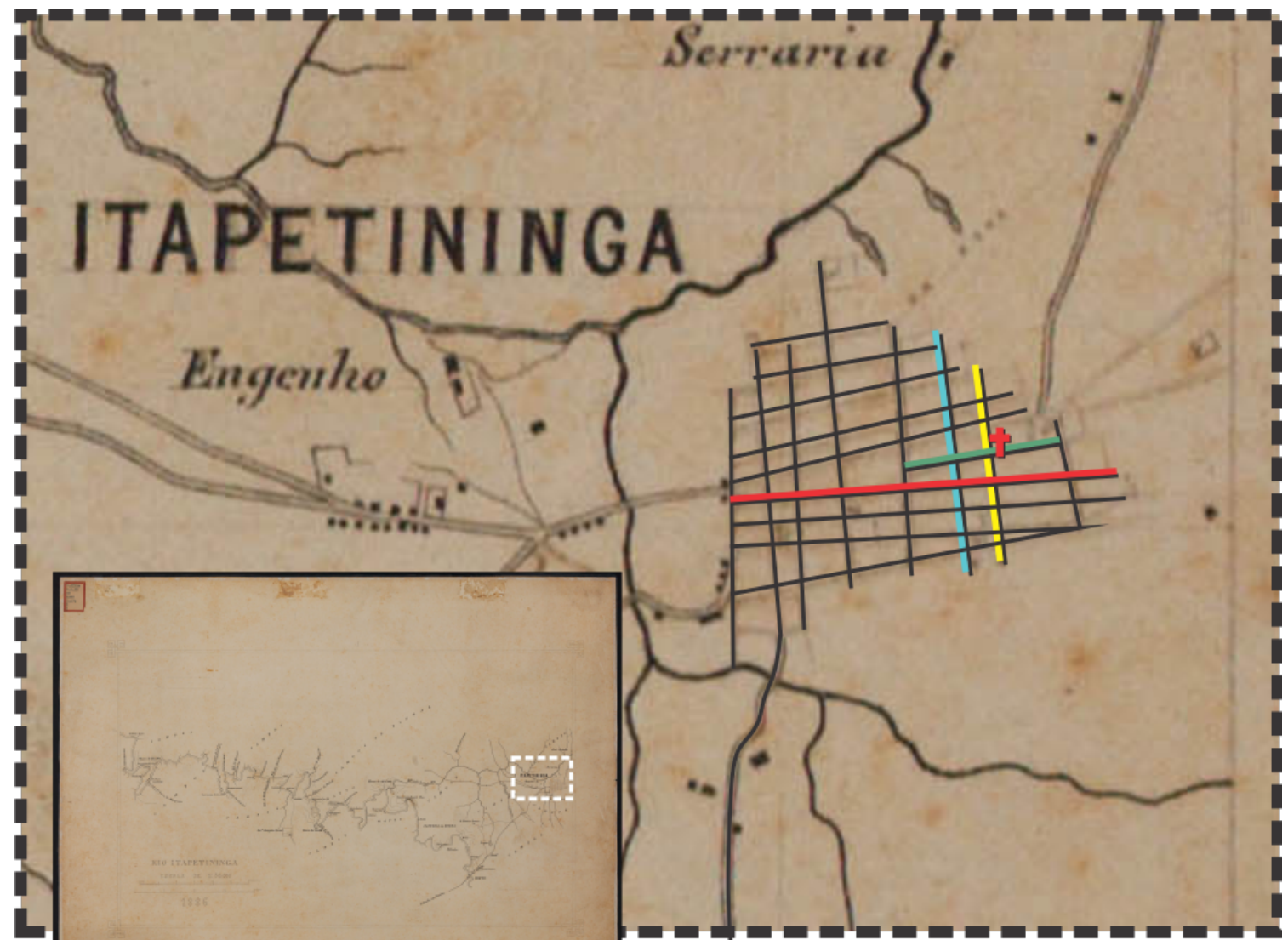

Figura 11. Interpretação da morfologia urbana de Itapetininga no século XVIII, sobre Mapa de 1886; e análise das permanências e rupturas da morfologia urbana original de Itapetininga na cartografia contemporânea. Fonte: Coleção de Plantas dos rios Paranapanema e Itapetininga da Comissão Geográfica e Geológica (CGG) de 1886 — Arquivo do Estado de São Paulo.

Aplicando a metodologia proposta, podemos observar nas Figuras 11 e 12 a presença das ruas destacadas com as mesmas cores segundo suas localizações, a Estrada Geral, em vermelho, que era a principal rota de ligação a Nordeste para a Vila de Sorocaba; hoje rua Expedicionários de Itapetininga. Ela fica, como em 1886, perpendicular a rua destacada em amarelo. A Igreja Matriz Nossa Senhora dos Prazeres, do período fundacional, permanece no mesmo local, no alinhamento da Rua Lopes de Oliveira, está destacada em polígono vermelho; hoje rua Lopes de Oliveira. Da praça cen- 
tral restaram dois espaços em meio à mancha urbana, em polígono verde. 0 pequeno ponto em destaque é a possível localização do primeiro pelourinho da cidade. Pode-se observar também, que pouco se alterou do paralelismo das ruas originais, mantendo-se muito do traçado primevo da fundação. Hoje muitos edifícios são percebidos na mancha urbana, o que acabou reduzindo a área da praça central, centro aglutinador e estruturador do espaço urbano.

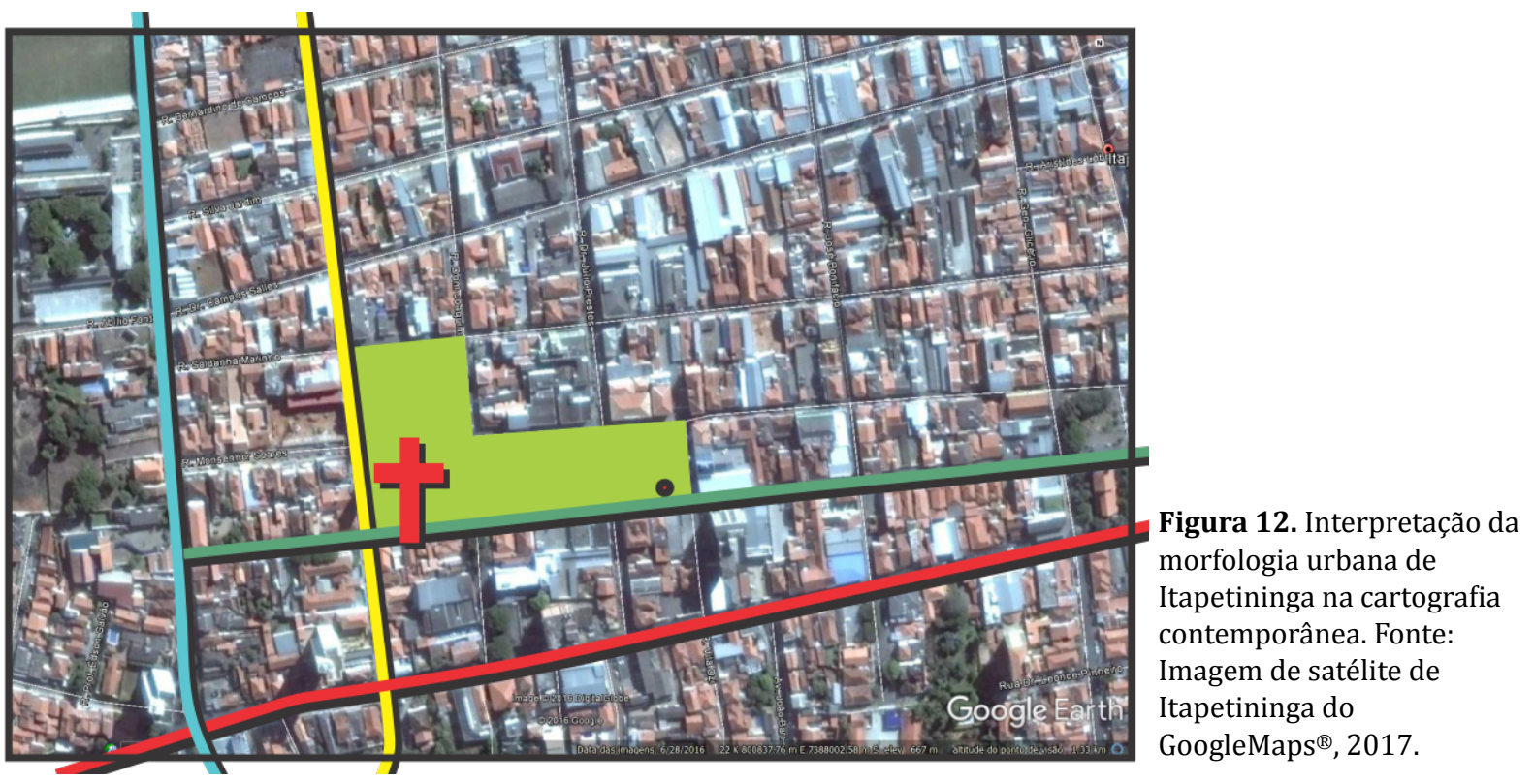

Na imagem contemporânea de satélite de Itapetininga (Figura 12) podemos ter uma ideia do que foi o núcleo fundacional da cidade de Itapetininga. Claramente se observa ao fundo a atual Igreja Matriz com a praça central. A praça do pelourinho, com as características da tradicional vila colonial portuguesa. No canto superior esquerdo observa-se a Estrada Geral do Sul, principal ligação com o caminho do Viamão, para Sorocaba e no sentido oposto, para o Sul.

Na Figura 13, abaixo, podemos ter uma ideia do que foi o núcleo fundacional da cidade de Itapetininga. Claramente se observa ao fundo a atual Igreja Matriz com a praça central, demarcada nos mapas anteriores. Ao lado temos a praça do pelourinho, com as características da tradicional vila colonial portuguesa. No canto superior esquerdo observa-se a Estrada Geral do Sul, principal ligação com o caminho do Viamão, para Sorocaba e no sentido oposto, para o Sul.

Figura 13.

Maquete núcleo fundacional de Itapetininga. Fonte: Museu Histórico de Itapetininga. Fotografia de Fábio Barros disponível em: $<\mathrm{http}: / /$ cidade3d.blogspot .com.br/ 2012/11/ maquetefundacao-deitapetininga.html> acessado em 20 de fevereiro de 2017 às $22 \mathrm{~h}$.

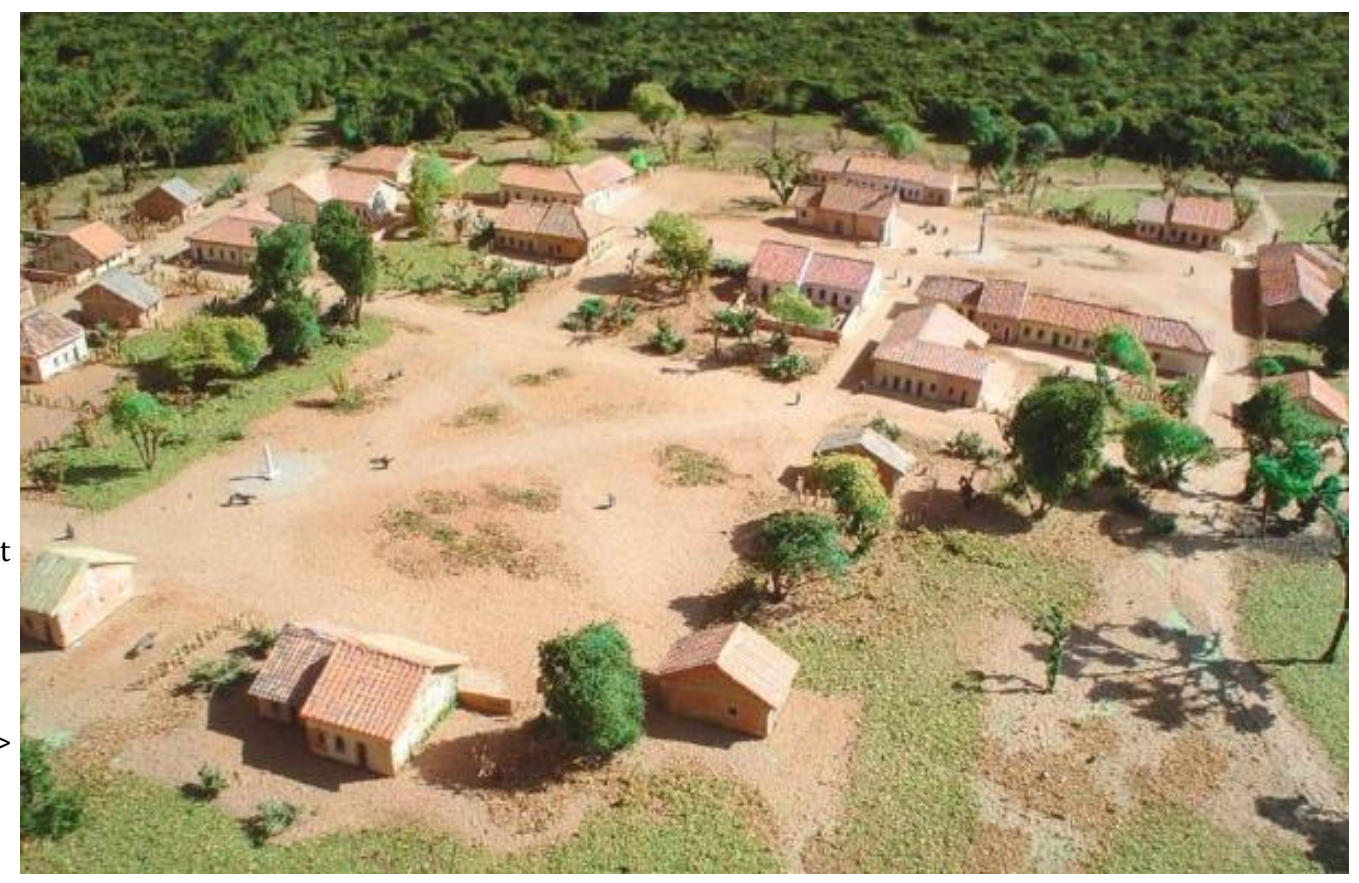




\subsubsection{A Vila de Itapeva}

A freguesia de Itapeva ficava a Sudoeste de Sorocaba, no eixo do caminho do Viamão entre Itapetininga e Apiaí, na rota que subia de Curitiba, participando do mesmo contexto mercantil e social do sul da capitania, como as duas vilas já analisadas. Segundo Araújo (2006), seu desenvolvimento foi impulsionado pela administração estratégica de Morgado de Mateus, que no ano de 1766, convoca interessados em povoar o pouso de Itapeva. Em documento de 1767, publicado no site do município, Antonio Furquim Pedroso reclama ao Governador, sobre a difícil tarefa de gerenciar a povoação em crescimento. Assim, Morgado de Mateus, através do ouvidor geral e corregedor da comarca de São Paulo, incumbe a Cláudio de Madureira Calheiros, Juiz ordinário da vila de Sorocaba, o estabelecimento de pelourinho para desmembramento e elevação à vila de Itapeva da Faxina, que se efetiva no ano de 1769.

Na análise morfológica proposta (Figuras 14 e 15), o traçado original da vila de Itapeva é interpretado por fontes historiográficas. 0 seu centro histórico atual é analisado através da imagem de satélite do GoogleMaps ${ }^{\circledR}$ de 2017. Podemos identificar a sua formação tipicamente Portuguesa típica das vilas coloniais do período, como referência para a tradição do modo de ocupação territorial, evidenciado também nas demais cidades.

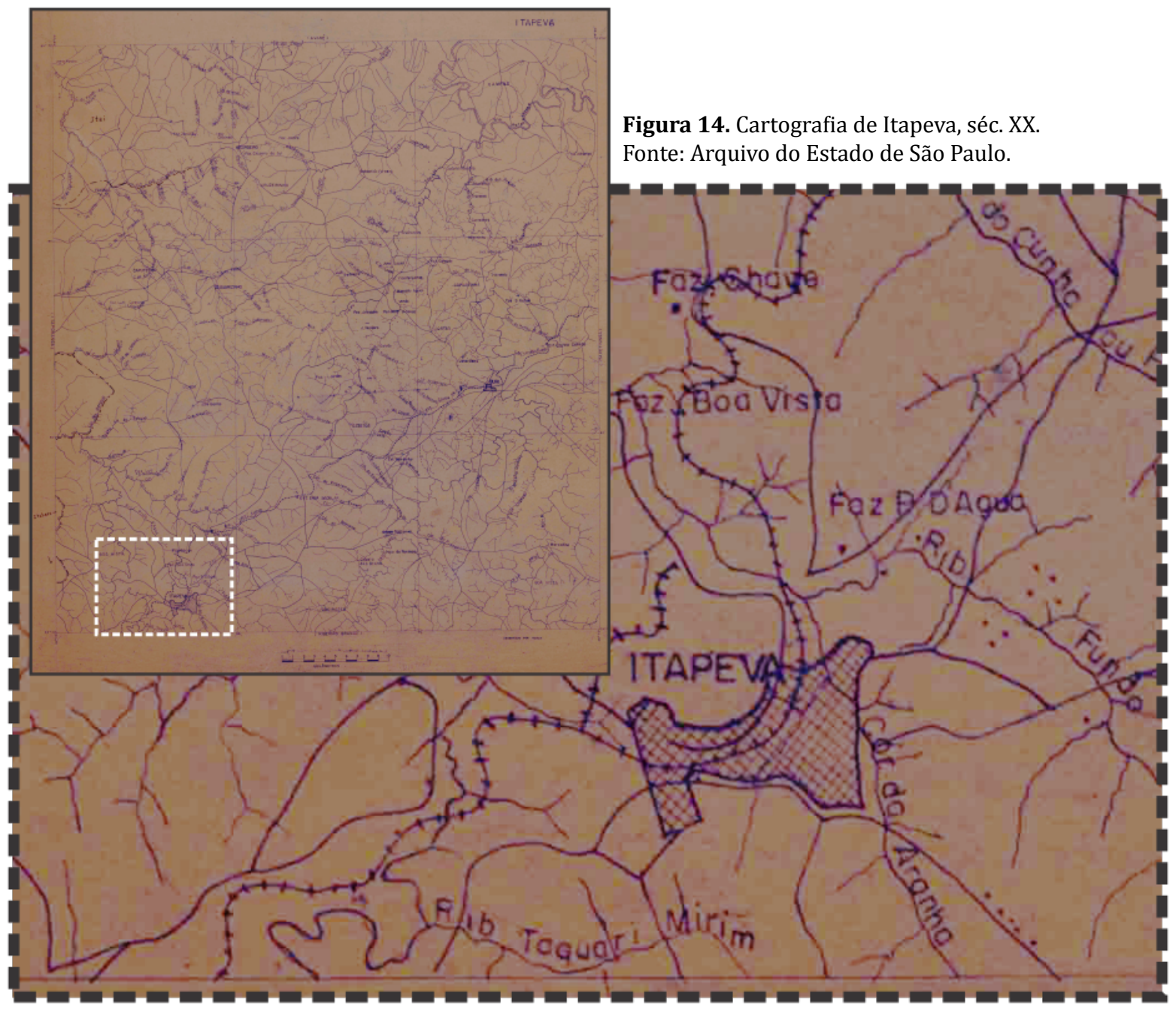

Observa-se que, apesar da falta de documentação para comprovar o traçado inicial, a ortogonalidade está presente na Itapeva contemporânea. A figura 14 mostra um mapa com a inserção da cidade em um contexto regional. A figura 15 evidencia: a praça central (polígono verde), junto à Igreja Matriz (cruz vermelha) que foi dedicada à Sant'Ana, fica lindeira à rua Ernesto de Camargo, evidenciada na Linha de cor verde. Também as ruas perpendiculares Dr. Pinheiro e Mario Prandini, respectivamente em Amarelo e Azul, permitem observar o paralelismo na conformação da malha urbana. Seu centro 
histórico caracteriza-se como principal núcleo de atividade econômica e centro administrativo até hoje, com os principais equipamentos públicos como prédios da prefeitura municipal, ministério e secretaria da fazenda, entre outros. Esses últimos relativos ao sistema político atual.

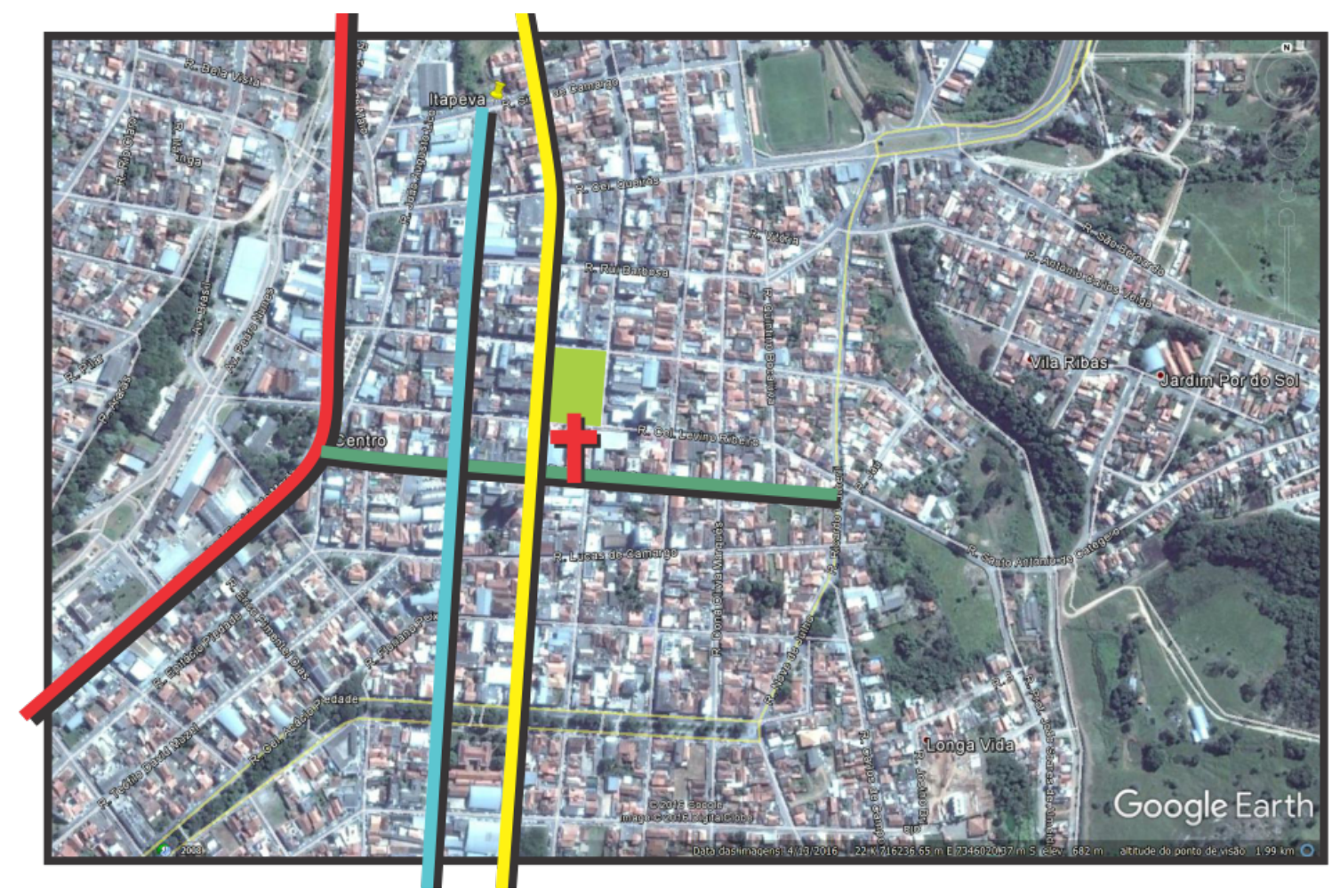

Figura 15. Núcleo Fundacional de Itapeva 2017. Fonte: Intervenção do Autor em imagem de satélite do GoogleMaps ${ }^{\circledR}$.

\section{Conclusão}

A interpretação cartográfica histórica permite um estudo morfológico das formações urbanas. Através desta perspectiva de análise pretende-se subsidiar políticas de preservação patrimonial, com destaque para seus aspectos arquitetônicos e urbanísticos, para fins de preservação do conjunto do seu patrimônio ou de seus vestígios de formação, do que se pode entender como caráter urbano de um assentamento.

Os estudos de caso das freguesias desmembradas do termo da vila Sorocaba no século XVIII, e elevadas à vila no governo do Morgado de Mateus, no contexto da ocupação sul da capitania de São Paulo, ao longo do Caminho do Viamão - Itapeva da Faxina (1769), Itapetininga (1771) e Apiaí (1771) - permitem construir subsídios para políticas de valorização patrimonial. Atentam-se aqui para as características de contemporaneidade e contexto das elevações de tais vilas. Elas possibilitam uma compreensão da rede de vilas formadas nesse período, seus papéis econômicos, sociais e políticos, colaborando para com a construção da história urbana destas cidades, das suas memórias e das suas identidades, sem nunca esgotar novas possibilidades de estudos no campo das pesquisas que ainda podem contribuir com esse processo.

O esforço do presente trabalho também foi de estabelecer um momento comum ao período estudado, em que as elevações a vila apresentadas compreendem relações, desde o traçado herdado de uma política urbanizadora iluminista para propiciar o rápido crescimento e expansão dessas vilas, até as características sociais, econômicas e políticas. Guardando uma relação de contexto na rede urbana e estabelecendo uma forte conexão com a figura de um mesmo fundador. Essa figura é, senão, o próprio Morgado de Mateus.

\section{Referências}

Araújo, S. A. C (2006). Arqueologia de Itapeva, SP: contribuição a formação de políticas públicas para gestão patrimonial. Dissertação de Mestrado, Universidade de São Paulo, Museu de Etnologia e Arqueologia. São Paulo, SP, Brasil. 
Araújo, R. M. et al. (2017). Heritage of Portuguese Influence Portal. Recuperado de: < http://www.hpip.org/ Default/en/Homepage $>$.

Bellotto, H. L. (2007). Autoridade e conflito no Brasil colonial: o governo do Morgado de Mateus em São Paulo. São Paulo: Conselho Estadual de Artes e Ciências Humanas.

Bonadio, G. (1984). O Tropeirismo e a formação do Brasil. Sorocaba: Academia Sorocabana de Letras; Fundação Ubaldino do Amaral.

Bueno, B. P. S. (2009). Dilatação dos confins: caminhos, vilas e cidades na formação da Capitania de São Paulo (1532-1822). Anais do Museu Paulista, 17 (2), São Paulo, pp. 251-294.

Derntl, M. F. (2010). Método e arte: criação urbana e organização territorial na capitania de São Paulo, 1765-1811. Tese de Doutorado, Universidade de São Paulo, Faculdade de Arquitetura e Urbanismo, São Paulo, SP, Brasil.

Luz, R. C. (1996) Santo Antonio das Minas de Apiahy. Apiaí. Recuperado de: <www.bibliotecadigital.gpme.org.br/bd/wp-content/uploads/eco/.../bd-gpme-0091.pdf> .

Marx, M. (1991). Cidade no Brasil, terra de quem? São Paulo: Nobel, 1991.

Reis, N. G. (1968). Contribuição ao estudo da evolução Urbana no Brasil (1500-1720). São Paulo: Edusp.

Reis, N. G. (2000). Imagens de Vilas e Cidades do Brasil Colonial (colaboradores Beatriz Piccolotto Siqueira Bueno, Paulo Júlio Valentim Bruna). São Paulo: Edusp; Imprensa Oficial do Estado de São Paulo; Fapesp.

Reis, N. G. (2013). As minas de ouro e a formação das Capitanias do Sul. São Paulo: Via das Artes.

Salgado, I., \& Pereira, R. B. (2014). A formação de núcleos urbanos no Brasil Colônia: procedimentos para elevar freguesias a vilas na Capitania de São Paulo na segunda metade do século XVIII. In Congresso Europeu de História Urbana, Lisboa: Anais.

Salgado, I. (2008). Fundação de freguesias, elevação de vilas e fortificação de praças na capitania de São Paulo (1765-1775): A gestão restauradora do Morgado de Mateus. Notícia Bibliográfica e Histórica, 202, pp. 15-37. PUC-Campinas.

Sampaio, T. F. (1886). Relatório apresentado ao Dr. Pedro Vicente de Azevedo, Presidente da Província de São Paulo em 1886, referente à exploração dos rios Itapetininga e Paranapanema. São Paulo: Comissão Geográfica e Geológica da Província de São Paulo, p.1. 